\title{
Larval description of Drusus muelleri McLachlan, 1868 (Trichoptera : Limnephilidae) with some notes on its ecology and systematic position within the genus Drusus
}

\author{
W. Graf ${ }^{1 *}$, V. Lubini² ${ }^{2}$ S. Pauls ${ }^{3}$ \\ ${ }^{1}$ BOKU - University of Natural Resources and Applied Life Sciences Vienna, Institute of Hydrobiology and Aquatic Ecology Management, \\ Max Emanuelstrasse 17, A - 1180 Vienna, Austria. \\ 2 Eichhalde 14, CH-8053 Zürich, Switzerland. \\ ${ }^{3}$ Department of Limnology and Conservation, Senckenberg Research Institute, Senckenberganlage 25, 60325 Frankfurt am Main, Germany.
}

\begin{abstract}
This paper presents a description of the hitherto unknown larva of Drusus muelleri McLachlan, 1868. Information on the morphological and genetic identification of this species is given, and the most important diagnostic features are illustrated. Its systematic position within genus Drusus is affirmed and some zoogeographical and ecological notes are added.
\end{abstract}

Keywords : Trichoptera, Drusus muelleri, fifth instar larva, description, identification, distribution, larval food, mitochondrial DNA.

\section{Introduction}

The subfamily Drusinae Banks, 1916 comprises eight genera, and 57 European species are placed presently among genus Drusus Stephens, 1837 (e.g. Kumanski 1973, Sipahiler 1999, 2002, Malicky 2002, 2004, Urbanic et al. 2003). Recently, larvae were found in Switzerland, which were genetically identified as $D$. muelleri based on sequence data from the mitochondrial cytochrome oxidase I (mtCOI) region (Pauls 2004). Their outstanding morphological features are presented in this paper.

\section{Morphological separation of Drusus muel- leri from other European Limnephilidae}

Drusus muelleri belongs to the subfamily Drusinae according to the following features (Waringer 1985, 1987, Szczesny 1978, Pitsch 1993, Waringer \& Graf

\footnotetext{
* Corresponding author : E-mail: wolfram.graf@boku.ac.at
}

1997, 2000):

- metanotum with three pairs of sclerites

- large, egg-shaped anteromedian sclerites on metanotum, their maximum width distinctly exceeds the distance between them

- all gills consist of single filaments only

- anterior third of pronotum lacks a distinctive rim

- all legs with additional setae on anterior faces as well as on dorsal side

The following features separate D. muelleri from other Drusinae known so far:

- a sharp bend of the frontoclypeus between the eye and anteclypeus (Fig. 1) which separates D. muelleri from all species of genera Ecclisopteryx Kolenati, 1848 and Drusus except D. chrysotus (Rambur, 1842), $D$. romanicus and $D$. discolor.

- mandibles with teeth around edges as in the species Cryptothrix nebulicola McLachlan, 1867, D. chrysotus, D. romanicus and D. discolor.

- a concavity within the head capsule surrounded by a rim, similar to but less pronounced than in D. chry- 
sotus, D. romanicus and D. discolor. C. nebulicola shows only shallow grooves along the lateral frontoclypeal edges.

- pronotum different from species of the genus $E c$ clisopteryx and most members of genus Drusus with a dorsal hump in caudal third, which is extended laterally (Fig. 2, 5). This feature is shared with Cryptothrix nebulicola, D. chrysotus, D. discolor and D. romanicus.

- no hair-like structures on pronotum and head (in contrast to $D$. discolor and $D$. romanicus).

Within the framework of the limnephilid key by Waringer \& Graf $(1997,2000)$, D. muelleri is keyed out

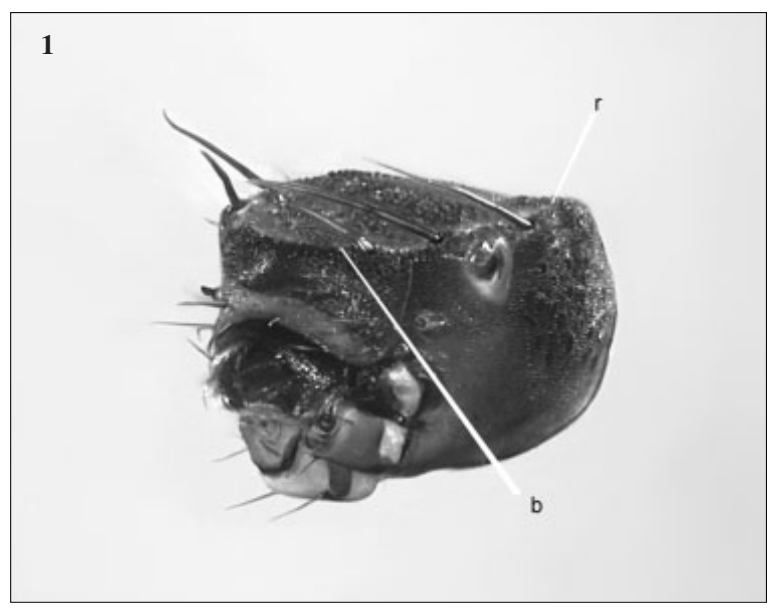

together with Drusus chrysotus. D. muelleri can be separated easily from the latter species by :

- a prominent prosternal horn, which is absent in $D$. chrysotus (the only member within the family Limnephilidae without prosternal horn).

- a shallow concavity of the head capsule, which is bordered by a ridge created by the parietalia (Fig. 1). In D. chrysotus the parietalia are strongly bent inwards in front of the eyes and in the adjacent dorsal and ventral parts producing a deep concavity and two sharp lateral ridges (Fig. 4).

- an isolated dense tuft of setae laterally present on second abdominal segment (Fig. 3). In D. chrysotus



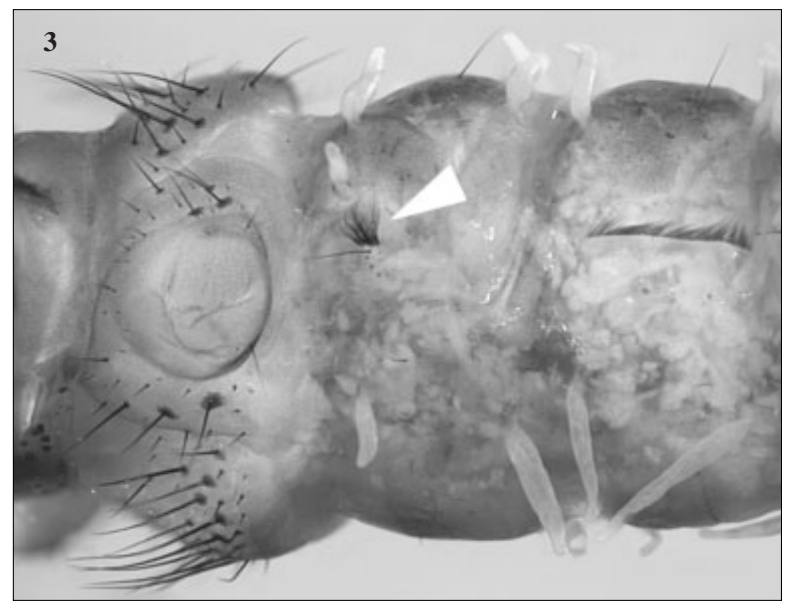

Figs 1-3. Drusus muelleri, fifth instar larva. Fig. 1 : head capsule, fronto-lateral view b: bend of frontoclypeus (pointer), r: ridge of parietalia (pointer); Fig. 2 : pronotum, dorsal view; Fig. 3 : abdominal segments I to III, lateral view, dense tuft of setae (arrow). 

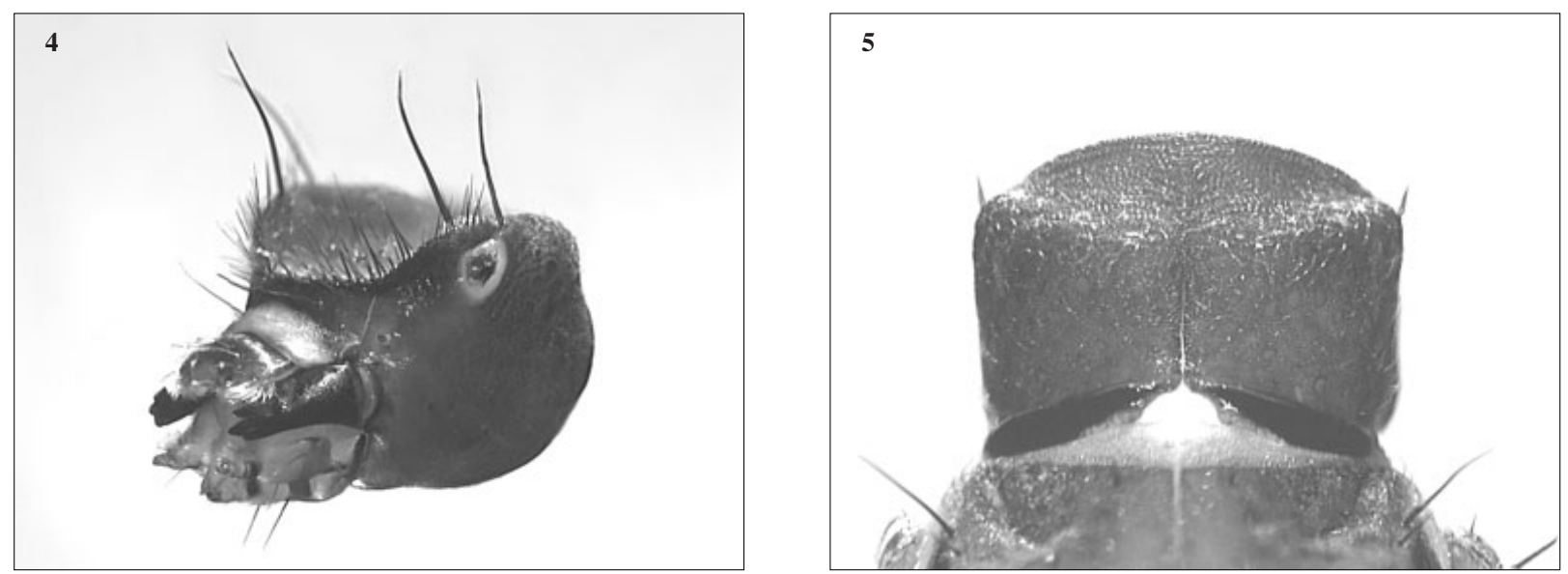

Figs 4-5. Drusus chrysotus, fifth instar larva : Fig. 4 : head capsule, fronto-lateral view; Fig. 5 : pronotum, dorsal view.

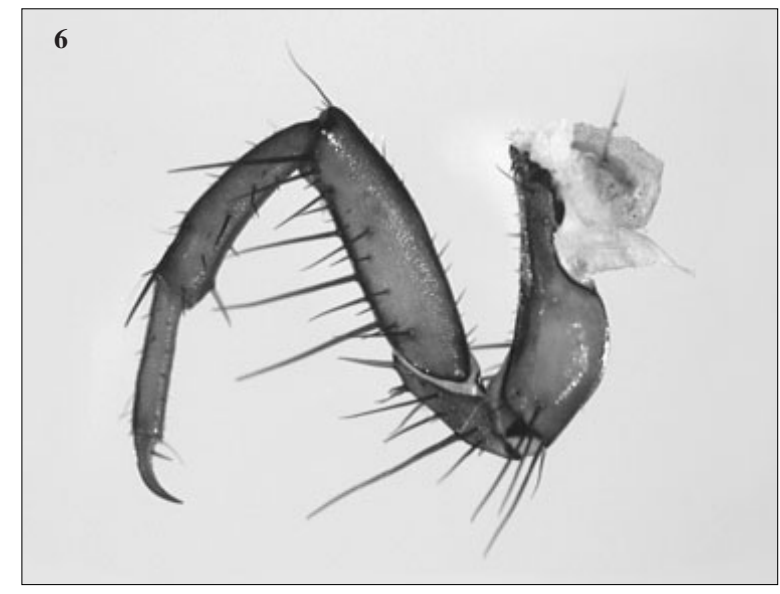

Fig. 6. Drusus muelleri, third leg, anterior view.

the lateral fringe is continuous and begins in the anterior third of the second abdominal segment.

- one pair of prominent median setae in the middle of the pronotum (Fig. 2), whereas D. chrysotus has very small setae at this position (Fig. 5).

- no additional setae on frontal ridge of the frontoclypeus (Fig. 1), which are present in D. chrysotus (Fig. 4).

\section{Material and methods}

Morphologically very distinct fifth larval stage specimens were collected from a spring brook in Switzerland, where the dominant adult was $D$. muelleri. To support species affiliation larval and adult specimens were genetically analysed by means of DNA nucleotide sequence analysis following the methods outlined in Pauls et al. (2003) and Pauls (2004). A 498 base pair (bp) long section of the mtCOI region revealed identical haplotypes between the larva and two adult males of Drusus muelleri (one from the same locality, one from the Meienreuss (Table 1$)$ ). A very similar $(0.2 \%$ sequence divergence; $1 \mathrm{bp}$ difference $\mathrm{C} / \mathrm{T}$ at position 295) haplotype was found in a third adult of D. muelleri from the Grimselsee tributary (Table 1). According to Schmid (1956) - and supported by Pauls (2004) - the putatively closest relatives of Drusus muelleri are $D$. discolor, D. chrysotus and D. romanicus. Uncorrected pairwise distances between haplotypes were calculated 
Table 1. mtCOI haplotypes of D. muelleri specimens.

\begin{tabular}{lllccc}
\hline Specimen & Locality & Lat./Long. & Haplotype & $\begin{array}{c}\text { Variable position } \\
\text { (position 295) }\end{array}$ & $\begin{array}{c}\text { Genbank } \\
\text { Accession } \\
\text { Number }\end{array}$ \\
\hline 1 male & Mutt tributary & $46.56^{\circ} \mathrm{N}, 8.38^{\circ} \mathrm{E}$ & $\mathrm{A}$ & $\mathrm{C}$ & $\begin{array}{c}\text { AY954398 } \\
\text { " larva }\end{array}$ \\
1 male & $\begin{array}{l}\text { Tributary to Grimselsee } \\
\text { (Grimselpass) }\end{array}$ & $46.55^{\circ} \mathrm{N}, 8.32^{\circ} \mathrm{E}$ & $\mathrm{A}$ & $\mathrm{C}$ & $\mathrm{AY} 954399$ \\
1 male & $\begin{array}{l}\text { Meienreuss } \\
\text { (Sustenspass) }\end{array}$ & $46.74^{\circ} \mathrm{N}, 8.45^{\circ} \mathrm{E}$ & $\mathrm{A}$ & $\mathrm{T}$ & $\mathrm{AY} 954401$ \\
& & & $\mathrm{C}$ & AY954400 \\
\hline
\end{tabular}

Table 2. Sequence divergence of mtCOI haplotypes of Drusus spp. closely related to D. muelleri.

\begin{tabular}{lccc}
\hline Species & $\begin{array}{c}\text { Nucleotide differences to } \\
\text { D. muelleri haplotype A }\end{array}$ & $\begin{array}{c}\text { sequence divergence to } \\
\text { haplotype A }\end{array}$ & $\begin{array}{c}\text { Genbank Accession } \\
\text { Number }\end{array}$ \\
\hline Drusus discolor* & $43-47 \mathrm{bp}$ & $8.43-10.24^{* *}$ & AY954396, AY954397 \\
D. chrysotus & $45 \mathrm{bp}$ & 8.6 & AY954395 \\
D. romanicus & $45-51 \mathrm{bp}$ & $8.43-10.09$ & AY954402, AY954403 \\
\hline
\end{tabular}

${ }^{*}$ closest and most divergent haplotype to haplotype A based on sampling from the entire species range (Pauls 2004) **total sequence divergence within D. discolor is 6.3\% (Pauls 2004)

for sequence data using Paup* 4.0 (Swofford 2001) and show high divergence to Drusus muelleri (Table 2). In a phylogenetic study of the Drusinae involving mtCOI sequence data from 115 specimens of 17 species of Drusinae, identical haplotypes were never shared between taxa, including very closely related species (e.g. D. romanicus Murgoci \& Botosaneanu, 1953 and D. discolor (Rambur, 1842), D. nigrescens MeyerDür, 1875 and D. monticola McLachlan, 1876). Interspecific sequence divergence was always greater than $1.8 \%$ (Pauls 2004). Similarly, in a congeneric study of Lepidostoma Rambur, 1842 Myers \& Sperling (2002) found intraspecific sequence divergence of closely related species to be at least $1.6 \%$ in the mtCOI region. These and other molecular studies on caddis flies have not shown introgression of mtCOI haplotypes (Myers et al. 2001, Kjer et al. 2001, 2002). Based on the identical haplotypes between larval and adult male specimens from the same locality, the previously unknown larva was identified as belonging to Drusus muelleri. The mtCOI sequence data of Drusus muelleri is summarised in Table 1.

Material examined for morphological description : Drusus muelleri : 3 fifth instar larvae from a small spring brook tributary to the Mutt river, collected by S. P. \& V. L. on July 17-18, 2004 (2060-2125 m a.s.l.; $\left.46.56^{\circ} \mathrm{N}, 8.38^{\circ} \mathrm{E}\right)$.

\section{Description of the fifth instar larva of Dru- sus muelleri}

(Head width $\geq 1.3 \mathrm{~mm}$ )

Head capsule width : 1.30-1.42 mm; head capsule, thoracic nota and legs blackish brown. Case slightly curved, constructed entirely of mineral particles. Head capsule with a shallow but distinct concavity, which is bordered by a sharp ridge of parietalia (Fig. 1). A sharp bend of the frontoclypeus is present between the eye and anteclypeus. Labrum is symmetrical, mandibles with teeth along edges. First thoracic sternite with prosternal horn. Thoracic legs short and robust, representing the clinger/filterer type. Additional setae present on anterior side of all legs. On femora extremely long additional spines (up to one third of femur length) on ventral side (Fig. 6).

First abdominal segment with numerous setae anterior to lateral protuberance as well as behind dorsal protuberance. Sternite with setae in two to three rows. Second abdominal segment with a dense tuft of setae in the first third of segment (Fig. 3). Lateral fringe extending from third to anterior third of eighth segment. Dorsolateral single gill filaments present from second to third segment, dorsal presegmental gills on segment two to five, dorsal postsegmental gills from segment two to seven, ventral pre- and postsegmental gills from segments two to five. Ventral chlorid epithelia visible 
from sternite four to seven. Ninth tergite with four long setae only.

\section{Habitat description, phenology and distri- bution}

Larvae of D. muelleri were collected in a crenal section of a small glacial catchment of the Swiss Alps near the Rhone glacier. The physico-chemical variables of the catchment have been described by Ilg et al. (2001). Water temperature of the groundwater and snowmelt fed tributaries was highest in August ranging from $8.6^{\circ} \mathrm{C}$ in the morning to $14.8^{\circ} \mathrm{C}$ in the evening. In June the water temperature was lower. In correspondence to the substratum, which is composed mainly of gneiss, the conductivity was low (123 to 253 $\mu \mathrm{S} / \mathrm{cm})$. Silica, sulphate and chloride concentrations were low. The bottom of the brook consisted of flat stones covered partially with mosses, mixed with gravel and silt. The larvae were found clinging underneath stones with a diameter of about 10 to $20 \mathrm{~cm}$. Other Trichopteran species observed at the site were Drusus biguttatus (Pictet, 1834), Drusus discolor and Drusus nigrescens. Further species recorded in June, August and September 1997 at the Mutt near the spring brook tributary by B. Lods-Crozet were Acrophylax zerberus Brauer, 1867, Anisogamus difformis McLachlan, 1867, Drusus melanchaetes McLachlan, 1868 and Rhyacophila intermedia (McLachlan, 1868) (Lods-Crozet et al. 2001).

Drusus muelleri seems to be a hypocrenal species, living near the source. This is in accordance to Siegenthaler-Moreillon (1991), who states that D. muelleri inhabits torrenticole brooks between $1600 \mathrm{~m}$ and 2600 $\mathrm{m}$ a.s.l. According to data from our collections and the Swiss Center of faunal cartography (CSCF as of October 2004), the species was found between $1900 \mathrm{~m}$ a.s.1. to $2450 \mathrm{~m}$ a.s.1. in the Swiss Alps.

In the Swiss Alps the flight period starts at the beginning of July and ends in the middle of August (CSCF as of October 2004). According to Malicky (2003) and data from CSCF (as of October 2004), D. muelleri is restricted to the central alps in Switzerland, France and Italy.

\section{Discussion}

Due to larval morphological features like the concave form of the head, the bend of frontoclypeus, additional setae and bristles on legs and $1^{\text {st }}$ abdominal segment, the shape of pronotum, mandibles with teeth as well as the coarsely sculptured surface of sclerites $D$. muelleri is classified close to three other species within the subfamily Drusinae, D. chrysotus, D. romanicus and $D$. discolor. A close relationship between these species was already recognized by Schmid (1956) based on genital morphology who placed them in two closely related species groups, the discolor-group ( $D$. discolor, $D$. chrysotus) and the muelleri-group ( $D$. muelleri, D. romanicus). This close relationship between all four species is also supported by molecular evidence from mtCOI sequence data (Pauls 2004, Pauls et al., in prep.). D. chrysotus and D. discolor are known to be carnivorous filterers (Bohle 1983, 1987) and although no ethological observations exist we assume on the basis of larval morphology the same feeding behaviour for $D$. muelleri, at least partially. Gut content analysis of 14 specimens of $D$. muelleri (head capsule width : 0.69 to $1.42 \mathrm{~mm}$ ) from the Mutt tributary revealed few chironomids like Orthocladiinae and Tanypodinae. The main food items seem to be detritus and leaf fragments of which the gut was dominantly filled. As many limnephilids, the species may switch to the break-up of coarse particulate organic material and can therefore be assigned as omnivorous shredder/filterer.

Although the species has not been reported frequently in the past - only 29 findings since 1888 - (Swiss Center of faunal cartography as of Oct. 2004), it was found in high abundances ( $>60$ individuals caught in 30 minutes at the Meienreuss) and represented the dominant species collected in all three localities. Most specimens were observed sitting on the ends of grass culms close to or overhanging the stream. Despite the warm, sunny weather (clear skies, $\sim 23^{\circ} \mathrm{C}$, slight wind) only few specimens were observed on the wing. Presumably adult are night-active and are attracted by signals from the opposite sex. Adults of the species, both male and female, exhibit a strong, pungent smell upon being caught. This compound may represent a sexual attractant. However, as it was only possible to detect the compound after catching, this may also serve defensive purposes.

The present study represents the first larval description of a caddisfly supported by genetic assignment. The marker, mtCOI sequence data, is often used to study intra- and interspecific relationships of various taxa including Trichoptera (Myers et al. 2001, Myers \& Sperling 2002, Pauls 2004). It has also proven useful in assigning individuals to a described taxon or different life stages of a species (Herbert et al. 2004, Moritz \& Cicero 2004, Pauls 2004). In the current study we support the association of larval and adult stages of 
Drusus muelleri collected from the same locality, as they carry identical haplotypes. Since introgression of mtCOI haplotypes is unknown from caddis flies and deviation to the closest related species was greater than $8.4 \%$ sequence divergence, we are confident that larvae and adults belong to the same species. The results thus exemplify how nucleotide sequence markers can facilitate and provide supportive evidence in taxonomic and systematic research.

\section{Acknowledgements}

The authors would like to thank Dr. Peter Haase (Senckenberg, Frankfurt) and Dr. H. Thorsten Lumbsch (Field Museum, Chicago) for financing the molecular analyses. We are grateful to Dr. Wolfgang Lechthaler (Eutaxa, Vienna) for providing the photographs. We also wish to thank Andrea Sundermann (Senckenberg, Frankfurt) for assistance in the field and the Swiss Center of faunal cartography, Neuchâtel, for the permission to publish the Swiss data. Two anonymous reviewers and Imke Schmitt (Field Museum, Chicago) are thanked for constructive criticism on earlier versions of this manuscript. This paper is part of the outcomes of a rearing of Central European Drusinae (Project number P18073-B03) funded by the Austrian Science Fund.

\section{References}

Bohle H.W. 1983. - Drift-catching and feeding behaviour of the larvae of Drusus discolor (Trichoptera, Limnephilidae). Arch. Hydrobiol., 97, 455-470.

Bohle H.W. 1987. - Drift-fangende Köcherfliegenlarven unter den Drusinae (Trichoptera: Limnephilidae). Entomol. Gener., 12, 119132.

Herbert P.D.N., Cywinska A., Ball S.L. \& deWaard J.R. 2003. - Biological identifications through DNA barcodes. Proc.R.Soc.Lond.B., 270, 313-321.

Herbert P.D.N., Penton E.H., Burns J.M., Janzen D.H. \& Hallwachs W. 2004. - Ten species in one : DNA barcoding reveals cryptic species in the neotropical skipper butterfly Astraptes fulgerator. PNAS, 101: 14812-14817.

Ilg C., Castella E., Lods-Crozet B. \& Marmonier P. 2001. - Invertebrate drift and physico-chemical variables in the tributaries of the Mutt, a Swiss glacial stream. Arch. Hydrobiol., 151, 335-352.

Kjer K.M., Blahnik R.J. \& Holzenthal R.W. 2001. - Phylogeny of Trichoptera (Caddisflies) : Characterization of Signal and Noise Within Multiple Datasets. Syst. Biol. 50, 781-816.

Kjer K.M., Blahnik R.J. \& Holzenthal R.W. 2002. - Phylogeny of caddisflies (Insecta, Trichoptera). Zool. Script., 31, 83-91.

Kumanski K. 1973. - Die Unterfamilie Drusinae (Trichoptera) in Bulgarien. Tijdschrift. Ent., 116 6, 107-121.

Lods-Crozet B., Castella E., Cambin D., Ilg C., Knispel S. \& MayorSimeant H. 2001. - Macroinvertebrate community structure in relation to environmental variables in a Swiss glacial stream. Freshwater Biology, 46, 1641-1661.

Malicky H. 2002. - Einige Köcherfliegen (Trichoptera) aus Frankreich und Italien. Entomofauna, 23, 1-12.

Malicky H. 2003. - Köcherfliegenfänge vom Gotthardpassgebiet (2090-2120 m), Kanton Tessin (Trichoptera). Entomol. Ber. (Lu- zern), 49, 21-22

Malicky H. 2004. - Neue Köcherfliegen aus Europa und Asien. Braueria, 31, 36-42, Lunz.

Mortiz C. \& Cicero C. 2004. - DNA Barcoding: Promise and Pitfalls. PloS Biology, 2, e279-e354.

Myers M.J. \&. Sperling F.A.H 2002. - Preliminary evaluation of subgeneric designations within the caddisfly genus Lepidostoma (RAMBUR) (Trichoptera: Lepidostomatidae) based on mtDNA sequences. Nova Suppl. Entom., 15, 187-194.

Myers M.J., Sperling F.A.H. \& Resh V.H. 2001. - Dispersal of two species of Trichoptera from desert springs : Conservation implications for isolated vs connected populations. J. Insect Cons., 5, 207-215.

Pauls S., Lumbsch H.T. \& Haase P. 2003. - Genetische Isolation von Drusus discolor Rambur 1842 (Trichoptera: Limnephilidae) in montanen Mittelgebirgen Mitteleuropas - Erste Ergebnisse. Deutsche Gesellschaft für Limnologie. Tagungsbericht, 2002, 378-379.

Pauls S. 2004. - Phylogeny and phylogeography of the montane caddis fly Drusus discolor (Rambur, 1842) (Trichoptera: Limnephilidae, Drusinae). PhD-Thesis, University of Duisburg-Essen. 1164.

Pitsch T. 1993. - Zur Larvaltaxonomie, Faunistik und Ökologie mitteleuropäischer Fließwasser-Köcherfliegen (Insecta: Trichoptera). Landschaftsentwicklung und Umweltforschung, Sonderheft 8 , $1-316$.

Schmid F. 1956. - La sous-famille des Drusinae (Trichoptera, Limnephilidae). Mem. Inst. Roy. Sci. Nat. Belgique, 2eme Series, 55, $1-92$.

Siegenthaler-Moreillon C. 1991. - Les Trichoptères de Suisse occidentale (Insecta, Trichoptera). Thesis, Univ. Lausanne,1-198.

Sipahiler F. 1999. - Distribution of Drusinae (Limnephilidae) species in Turkey. Proc. 9th Intern. Symp. Trichoptera 1998, Chiang Mai, Thailand. 1999, 329-336.

Sipahiler F. 2002. - Hadimina torosensis, new genus and new species of Drusinae from southern Turkey (Trichoptera: Limnephilidae). Nova Suppl. Entom., 15, 239-248.

Swofford D.L. 2001. - PAUP*. Phylogenetic analysis using parsimony (*and other methods). Ver. 4.0b10. Sunderland: Sinauer Associates.

Szczesny B. 1978. - Larvae of the subfamily Drusinae (Insecta :Trichoptera) from the Polish part of the Carpathian Mts. Acta Hydrobiol., 20, 35-53.

Urbanič G., Waringer J. \& Graf W. 2003. - The larva of Ecclisopteryx asterix Malicky, 1979 (Trichoptera : Limnephilidae:Drusinae). Lauterbornia, 46, 125-135, Dinkelscherben.

Waringer J. 1985. - The larva of Metanoea rhaetica Schmid, 1955 (Trichoptera: Limnephilidae) from a small Austrian mountain brook. Aquat. Insects, 7, 243-248.

Waringer J. 1987. - The larva of Drusus chrysotus (Rambur,1842) (Trichoptera : Limnephilidae) from an Austrian brook. Aquat. Insects, 9, 21-25.

Waringer, J. \& Graf W. 1997. - Atlas der Österreichischen Köcherfliegenlarven. Facultas Univeritätsverlag, Wien, 286 p.

Waringer, J. \& Graf W. 2000. - Ergänzungen und Berichtigungen zum «Atlas der österreichischen Köcherfliegenlarven unter Einschlufl der angrenzenden Gebiete». Beilage zum 1. unveränderten Nachdruck. Facultas Universitätsverlag, Wien, 19 p. 